\title{
ANALYSIS OF THE EFFECT OF SERVICE RECOVERY ON CUSTOMER LOYALTY WITH SATISFACTION AND WOM (WORD OF MOUTH) AS MEDIATION VARIABLES AT FOUR-STAR HOTELS IN BATAM CITY
}

\author{
Lily Purwianti ${ }^{1)}$, Lidya Siska Khoviati ${ }^{2)}$ \\ ${ }^{1,2)}$ Universitas Internasional Batam, Riau Islands, Indonesia \\ Corresponding author: lily.purwianti@uib.ac.id
}

\begin{abstract}
The purpose of this study was to analyze the effect of service recovery variables consisting of distributive justice, procedural justice, and interactional justice on customer loyalty with satisfaction and WOM as a mediating variable in star hotels in Batam city. The sample of this research is local tourists who have stayed at four-star hotels in Batam City. The study results indicate the importance of a service provider to find out what consumers want by paying attention to constructive criticism to improve services that were previously not adequate. Suppose the customer feels that the service recovery provided is appropriate and satisfied with it. In that case, the customer often returns with the status of a loyal visitor and recommends it to others.
\end{abstract}

Keywords: Service Recovery, Customer Satisfaction, Word of Mouth, Customer Loyalty

\section{Introduction}

Hotels are one of the lodging places that have a broad economic impact, especially for business people. Hotels are needed accommodation for tourists who want to do tourist destinations, so that this has an impact on the economic development of the surrounding community and regional income. The hotel industry is a significant contributor to the advancement of the tourism industry. For more than six decades, tourism has continued to develop and continuously diversify, thus affecting the economic sector in the world (UNWTO, 2017). Hotel accommodation services have an impact on tourist visits. With a good hotel and exemplary service, tourists can return to accommodation to people around them and become the choice of accommodation for tourists in the future. The growth of hotels in Batam City, which is overgrowing, has an essential role in attracting the attention of rising people to visit Batam City.

The latest BPS data in November 2020 shows a significant change, namely the decrease in the number of visits by travelers staying at star hotels in the Riau Islands Province with $24.64 \%$. The value of Room Occupancy Rates at 4-star hotels reaches 26.27\% (Badan Pusat Statistik, 2020). The drastic decrease in the number of visits by travelers was caused by the coronavirus disease that hit the city of Wuhan in China in December 2019. This situation continued until 2020, when the spread of the virus had entered a pandemic stage throughout the world, which resulted in many countries closing or locking down, including Batam City in Indonesia. (Laoly, 2020).

This regulation ultimately has a significant impact on the hotel industry. The number of people staying has decreased, and even many hotels have not operated during the pandemic period until a conducive situation has occurred. In the new standard era, the hotel industry started operating again. This is indicated by the opening of hotels in Batam City. Most visitors are local tourists because other countries shut themselves off from visiting other countries and even prohibited their citizens from leaving (Vero, 2020). The occupancy rate of four-star hotels in November 2020 will be 1.39 days (Badan Pusat Statistik, 2020).

In this case, service recovery has a somewhat important position because it leads to actions implemented by service providers in responding to a complaint is originating from service users due to the failure of a service. Through this service failure, the service recovery procedure is very relevant in dealing with the satisfaction and loyalty of service users (Cheng et al., 2019). If a service failure occurs, the service user will experience an unpleasant experience or feel dissatisfied with the service. This results in disappointment from the bad experiences so that in the end, it will be spread to friends depending on the intensity of their dissatisfaction (Cheng et al., 2019). The dissemination of information by word of mouth will significantly affect the repeated use of services by service users and determine loyalty (Ntale \& Ngoma, 2019). It can be concluded that the impact of service recovery has a significant effect on the loyalty of service users because when someone is satisfied with a service, it is possible that someone will spread positive information by word of mouth to the surrounding people and even become someone with a loyal status in that place.

Considering the importance of the role and involvement of hotel services for the economic development of the community in Batam City, the researchers are encouraged to further study the "Analysis of the Effect of Service Recovery on Customer Loyalty with Satisfaction and WOM (Word of Mouth) as Mediation Variables in Four Star Hotels in Batam City." 


\section{Literature Review}

According to researchers (Cheng et al., 2019), customer loyalty is a significant focus that organizations must hold closely, especially in dealing with problems that arise until they reach the settlement stage so that the company can maintain this relationship. According to researchers (Hikmah et al., 2018), customer loyalty in marketing, repeat purchases, and willingness to recommend to prospective buyers are usually used as indicators to show loyalty.

Service recovery is a challenge for companies in providing needs and services to consumers in responding to complaints from service users due to service failures. This indicator of service recovery will affect perceptions of fairness and satisfactory customer results (Cheng et al., 2019). Service recovery is considered one of the most critical customer service strategies because it is the ability of how the company responds and fixes service failures that are protested by service users to be better, so that customer satisfaction, repurchase intentions, trust, commitment, and positive communication arise word of mouth (Yunus \& Rashid, 2016). Satisfaction is a significant problem in service failure and acts as a recovery process carried out by service providers. Based on the explanation above, the research hypothesis is:

\section{H1: Service Recovery has a positive effect on satisfaction}

Satisfaction is closely related to business because it shows repeat purchases and positive word-of-mouth recommendations. Recommendations to others and repeat purchases can usually be said that service users are loyal, whereas revisiting is desirable because marketing costs are lower than necessary. Both of these show satisfaction indicators that have a positive impact (Breiby \& Slåtten, 2018). Usually, loyal service users tend to resist changes in service providers and still maintain services that are already satisfied. If the customer is satisfied with the services provided, the customer's intention to visit again will increase (Mlozi, 2015). Satisfaction will show an emotional reaction that is influenced by expectations that are following the interests of service users, whether it is following the level of service they want or vice versa, then this satisfaction will increase the intention to continue to buy back, always want to use the facilities that have been provided previously and provide recommendations for facilities that are available to use on others (Tan et al., 2017). Based on the explanation above, the research hypothesis is:

\section{H2: Satisfaction has a positive effect on Customer Loyalty}

Satisfaction becomes concrete for service providers because a positive spread can improve the organization's reputation that offers the service. However, if service users are disappointed, they will prevent other people from making purchases (Nuns, 2017). Word of mouth is a type of direct and tangible communication so that affects the decisions of service users. Increasing trust by word of mouth can foster satisfaction with service recovery. Satisfaction is a way to increase one's intention to return to using available services and even recommending it to others (Velazquez et al., 2015). Service users who have a higher level of satisfaction will generate a sense of intention to visit again. Intending to visit again, service users also tend to recommend goods or services purchased to others. Service users who are satisfied with the services available will usually communicate about the service and always comment positively about the service (Sridhar \& Ganesan, 2016). Based on the explanation above, the research hypothesis is:

\section{H3: Satisfaction has a positive effect on WOM (Word of Mouth)}

A recommendation will be made by someone if the service user has experienced the service. Customer loyalty is related to behavior and attitudes, where the view of this behavior refers to customer behavior in repeated purchases of a particular brand or service. In contrast, the view of attitudes is based on the intention of service users to repurchase and recommend to others by managing positive attitudes towards the company (Cantallops et al., 2018). By speaking positively about the company and its offerings, service users can promote new and repeat purchases (Ntale \& Ngoma, 2019). The spread of word of mouth positively by service users also affects service user loyalty which determines the attitude and behavior of service users in implementing marketing. Ideas in word of mouth usually describe information, a positive image of company services, and brands that can be achieved from one service user to another (Nikhashemi et al., 2015). Based on the explanation above, the research hypothesis is:

\section{H4: WOM (Word of Mouth) has a positive effect on Customer Loyalty}

Service recovery can be interpreted as an attitude taken by a company in response to a failure of a service. The goal of service restoration is to convert initially dissatisfied customers into satisfied ones. If a service failure occurs, it can cause dissatisfaction with service users. It can trigger service users to switch to other competitors who, in the end, are not loyal to service users (Ramanjaneyulu \& Acharyulu, 2018). If the service is restored effectively, it will cause satisfaction to service users. If service recovery is also based on complaints from service users, service users will feel cared for and can thrill service users to become loyal (Rossmann et al., 2017). Satisfaction of service users contributes to service recovery and has a direct impact on consumer attitudes and behavior. Service recovery in response to service failures will help improve service user satisfaction. Service user satisfaction that produces a positive impact will be embedded in loyal 
behavior and attitudes in service users (Tsao, 2018). Based on the explanation above, the research hypothesis is:

H5: Service recovery has a positive effect on Customer Loyalty with Satisfaction as an Intervening Variable

When a person shares experiences with others, a strong perception will arise in the minds of others, from initially listening to the assumption that the other person feels served. Suppose the recovery of this service is not following the expectations of service users. In that case, there will be feelings of disappointment in service users and harmful information dissemination, which causes customers to become disloyal (Iqbal \& Siddiqui, 2019). Based on the explanation above, the research hypothesis is:

\section{H6: Satisfaction has a positive effect on Customer Loyalty with WOM as an Intervening Variable}

Service users who are satisfied with the implemented service recovery will be involved in the intention to visit again. Of course, with this satisfaction, service users will recommend the services provided to their surrounding relatives (Akinci \& Aksoy, 2019). This satisfaction results in loyalty from service users, resulting in positive word-of-mouth communication. When an organization uses service recovery to resolve service user dissatisfaction, service users will feel satisfied with this service recovery and will also be loyal and willing to recommend the company to people around them because they feel that they respect their feelings (Mc Cain \& Lolli, 2016). Repurchase intentions and intentions of word of mouth will highlight the expectation that service users are satisfied. The intention to buy back focuses on assessing service users about purchases whose services are the same as those previously purchased in the future (Ding \& Lii, 2016). Effective service restoration will assist service providers in retaining existing service users and increase service user loyalty, resulting in positive word of mouth (Ellyawati, 2017). Based on the explanation above, the research hypothesis is:

\section{H7: Service Recovery has a positive effect on WOM with Satisfaction as an Intervening Variable}

\section{Research Method}

In this study, the population used is local tourists who come to Batam City, while the sample of this research is local tourists who stay at four-star hotels in Batam. The choice of a four-star hotel is in terms of the BPS (Central Statistics Agency), which states that the occupancy rate of star-rated hotel rooms in the Riau Islands Province in November 2020 is the highest in four-star hotels with a figure of $26.27 \%$ (Badan Pusat Statistik, 2020) is different from star hotels in December 2019 where the highest was located in fourstar hotels with a more dominant percentage. The sample size was taken using a comparison from (Hair et al., 2014), where the comparison used the 1:10 parameter; in each statement, the research variable represented ten respondents. So with the number of statements totaling 26 statements, the minimum sample required is 260 respondents, but to avoid data reduction and improve data accuracy, 300 questionnaires were distributed. The number of research questionnaires was 320 respondents with a purposive sample technique. The service recovery variable is adopted from the statement (Cheng et al., 2019), consisting of 12 statements. The satisfaction variable has 4 statement items adopted from (Cheng et al., 2019), WOM, which has 4 statement items adopted from (Wang et al., 2017), and customer loyalty which has 6 statement items according to (Cheng et al., 2019). The measurement scale uses a 5-point Likert scale.

\section{Result and Discussions \\ Validity Test and Reliability Test}

In the validity test that has been carried out, it can be concluded that in the AVE table, all question items are declared valid because they have a value greater than 0.5 , with service recovery $(0.553)$, satisfaction (0.739), word of mouth (0.738), and customer loyalty (0.646).

Based on the reliability test that has been carried out, it can be concluded that in the Cronbach's alpha table all variable are declared reliable because they have a value that is greater than 0.5 , with service recovery (0.926), satisfaction (0.882), word of mouth (0.881), and customer loyalty (0.890).

\section{Hypothesis Testing}

In the table path coefficients, it is said to be significant if it has a T-Statistics value $>1.96$ or P-Values < 0.05 . Based on the path coefficients in table $1, \mathrm{H} 1$ is significantly positive with a P-Value of 0.000 and Tstatistic of 5.768, H2 is significantly positive with a P-Value of 0.000 and T-statistic of $16.763, \mathrm{H} 3$ is significantly positive with a P-Value of 0.000 and T-statistic of 20.895 , H4 is significantly positive with PValue of 0.000 and T-statistic of 8.509, $\mathrm{H} 5$ is significantly positive with P-Value of 0.000 and T-statistic of 11.462, H6 is significantly positive with P-Value of 0.000 and T-statistic of 5.262, and H7 is significantly positive with P-Value of 0.000 and T-statistic of 6.808 . 
Table 1. Hypothesis Testing

\begin{tabular}{lccc}
\hline \multicolumn{1}{c}{ Hypothesis } & T-statistic & P-Value & Conclusion \\
\hline Satisfaction $\rightarrow$ Customer Loyalty & 5.768 & 0,000 & H1: Significantly Positive \\
\hline Satisfaction $\rightarrow$ Word of Mouth & 16.763 & 0,000 & H2: Significantly Positive \\
\hline Service Recovery $\rightarrow$ Satisfaction & 20.895 & 0,000 & H3: Significantly Positive \\
\hline Word of Mouth $\rightarrow$ Customer Loyalty & 8.509 & 0,000 & H4: Significantly Positive \\
\hline Service Recovery $\rightarrow$ Satisfaction $\rightarrow$ Word of Mouth & 11.462 & 0,000 & H5: Significantly Positive \\
\hline $\begin{array}{l}\text { Service Recovery } \rightarrow \text { Satisfaction } \rightarrow \text { Customer } \\
\text { Loyalty }\end{array}$ & 5.262 & 0,000 & H6: Significantly Positive \\
\hline Satisfaction $\rightarrow$ Word of Mouth $\rightarrow$ Customer Loyalty & 6.808 & 0,000 & H7: Significantly Positive \\
\hline
\end{tabular}

The results of H1 are following the research implemented by (Cheng et al., 2019); (Yunus \& Rashid, 2016), it can be concluded that the better the service improvements provided by service providers include distributive justice, such as compensating service users with fair consideration between the two parties. The results of H2 are following the research implemented by (Breiby \& Slåtten, 2018); (Mlozi, 2015); (Tan et al., 2017), it can be concluded that the more satisfied service users are using the services provided, it will have an impact on continuous use until loyal service users appear. The results of $\mathrm{H} 3$ are following the research implemented by (Nuns 2017; Sridhar \& Ganesan, 2016; Velazquez et al., 2015), it can be concluded that the more happy service users are using the services provided, it will have an impact on spreading information positively by word of mouth. The results of $\mathrm{H} 4$ are following the research implemented by (Cantallops et al., 2018; Nikhashemi et al., 2015; Ntale \& Ngoma, 2019), it can be concluded that the more information spread by word of mouth to other people, be it close relatives or others, the more curiosity will arise about these services. Thus those who receive the information will find out and try to stay at the place that has been recommended previously. If what their relatives say about good service is appropriate, then it is possible that those who have been recommended will come back continuously to become loyal service users.

The results of $\mathrm{H} 5$ indicate that satisfaction is proven to be able to significantly mediate service recovery with word of mouth. This result is following the study conducted by (Akinci \& Aksoy, 2019; Ding \& Lii, 2016; Mc Cain \& Lolli, 2016); (Ellyawati 2017). Customer loyalty will arise when you feel valued, leading to positive word of mouth between service users, one service user to another, either via electronic or nonelectronic. The results of H6 state that satisfaction is proven to be able to mediate service recovery with customer loyalty significantly. This result is following the study conducted by (Ramanjaneyulu \& Acharyulu, 2018; Rossmann et al., 2017; Tsao, 2018), it can be defined that when the third repair service recovery is implemented very well by service providers and according to customer requests, service users will feel happy because they feel their criticisms and complaints are heard and responded to. Through good handling by service providers, the good experiences that service users experience may be channeled by returning to the place. The results of $\mathrm{H} 7$ suggest that word of mouth is proven to be able to mediate satisfaction with customer loyalty significantly. This result follows the study conducted by (Iqbal \& Siddiqui, 2019), which can be concluded that if service providers can resolve complaints submitted by service users, it can positively disseminate information to others.

\section{Conclusion}

The results indicate that service recovery is a complex process in which each dimension (distributive justice, procedural justice, interactional justice) positively affects satisfaction. Customers consider the three dimensions to be quite substantial; if they are missing, it will cause customer dissatisfaction. In addition, satisfaction has a positive effect on WOM and customer loyalty, which shows that service recovery is to restore customer satisfaction and increase customer loyalty and WOM. To encourage and ensure that customers visit again, the services provided must also be following customer wishes. Service failures must be kept to a minimum to create satisfaction and loyalty to customers.

\section{References}

Akinci, S., \& Aksoy, S. (2019). The impact of service recovery evaluation on word-of-mouth intention: A moderated mediation model of overall satisfaction, household income, and gender. Tourism Management Perspectives, 31, 184-194. https://doi.org/10.1016/j.tmp.2019.05.002

Badan Pusat Statistik. (2020). Perkembangan Pariwisata Kota Batam November 2020 (Issue 09).

Breiby, M. A., \& Slåtten, T. (2018). The role of aesthetic experiential qualities for tourist satisfaction and loyalty. International Journal of Culture, Tourism, and Hospitality Research, 12(1), 1-14. https://doi.org/10.1108/IJCTHR-07-2017-0082

Cantallops, A. S., Cardona, J. R., \& Salvi, F. (2018). The impact of positive emotional experiences on eWOM generation and loyalty. Spanish Journal of Marketing - ESIC, 22(2), 142-162. https://doi.org/10.1108/SJME-03-2018-0009 
Cheng, B. L., Gan, C. C., Imrie, B. C., \& Mansori, S. (2019). Service Recovery, Customer Satisfaction, and Customer Loyalty: Evidence from Malaysia's Hotel Industry. International Journal of Quality and Service Sciences, 11(2), 187-203. https://doi.org/10.1108/IJQSS-09-2017-0081

Ding, M. C., \& Lii, Y. S. (2016). Handling online service recovery: Effects of perceived justice on online games. Telematics and Informatics, 33(4), 881-895. https://doi.org/10.1016/j.tele.2016.02.001

Ellyawati, J. (2017). Double Deviation Investigation Of Perceived Service Recovery Justice : A Study On The Indonesian Airline Industry. 33(6), 1263-1272.

Hair, J. F., Black, J. W. C., Babin, B. J., \& Anderson, R. E. (2014). Multivariate Data Analysis. In British Library Cataloguing (Seventh Ed). Pearson Education Limited. https://doi.org/10.4324/9781351269360

Hikmah, Payangan, O. R., Munir, A. R., \& Jusni. (2018). The effects of tourism products, service quality, and destination uniqueness on the satisfaction and loyalty of tourists in South Sulawesi. Scientific Research Journal, 6(1), 91-100.

Iqbal, S., \& Siddiqui, D. A. (2019). The Impact of Deceptive Advertising on Customer Loyalty: A case of Telecommunication Industry in Karachi, Pakistan. International Journal of Industrial Marketing, 4(1), 39. https://doi.org/10.5296/ijim.v4i1.14607

Laoly, Y. H. (2020). Berita Negara. Menteri Kesehatan Republik Indonesia Peraturan Menteri Kesehatan Republik Indonesia, Nomor 65(879), 2004-2006. https://doi.org/10.1093/bioinformatics/btk045

Mc Cain, S. L. C., \& Lolli, J. (2016). an Empirical Investigation Into Customer Satisfaction With Travel Agencies 'Service Recovery Efforts in Taiwan. 1.

Mlozi, S. (2015). Loyalty program in Africa: Risk-seeking and risk-averse adventurers. Tourism Review, 69(2), 137-157. https://doi.org/10.1108/TR-10-2013-0057

Nikhashemi, S. R., Paim, L., Osman, S., \& Sidin, S. (2015). The Significant Role of Customer Brand Identification towards Brand Loyalty Development: An Empirical Study among Malaysian Hypermarkets Customer. Procedia - Social and Behavioral Sciences, 207, 182-188. https://doi.org/10.1016/j.sbspro.2015.10.086

Ntale, P. D., \& Ngoma, M. (2019). Word of mouth communication: A mediator of relationship marketing and customer loyalty. Cogent Business and Management, 6(1). https://doi.org/10.1080/23311975.2019.1580123

Nuns, W. (2017). Loyalty Program and Word of Mouth in Educational Context: A Test of Moderation. November, 48-63. http://ijbassnet.com/

Ramanjaneyulu, \& Acharyulu. (2018). A Study On Service Recovery Quality Of Electronic Shopping Customers In India. 2(17), 135-140.

Rossmann, A., Wilke, T., \& Stei, G. (2017). Usage of Social Media Systems in Customer Service Strategies. Proceedings of the 50th Hawaii International Conference on System Sciences (2017), 3950-3959. https://doi.org/10.24251/hicss.2017.477

Sridhar, M., \& Ganesan, P. (2016). The Effect of Corporate Social Responsibility on Customer Performance and Behavioral Intention -Testing the mediating role of reputation of a private university. Great Lakes Herald, 10(10), 1-37.

Tan, T. S., Chen, T. L., \& Yang, P. H. (2017). User satisfaction and loyalty in a public library setting. Social Behavior and Personality, 45(5), 741-756. https://doi.org/10.2224/sbp.5999

Tsao, W. C. (2018). Star power: the effect of star rating on service recovery in the hotel industry. Unit 07, 15.

Velazquez, B. M., Molina, M. E. R., \& Gardo, T. F. (2015). Satisfaction with service recovery: moderating effect of age in word-of-mouth. Journal of Consumer Marketing, 32(6), 470-484. https://doi.org/10.1108/JCM-12-2014-1251

Vero, A. (2020). Terlihat Titik Terang, Hidupkan Kembali Pariwisata di Batam Kondisi Corona WartaKepri.co.id. https://wartakepri.co.id/2020/08/08/terlihat-titik-terang-hidupkan-kembali-pariwisatadi-batam-kondisi-corona/

Wang, T. L., Tran, P. T. K., \& Tran, V. T. (2017). Destination Perceived Quality, Tourist Satisfaction, and Word of Mouth. Unit 07, 1-5.

Yunus, N. S. N. M., \& Rashid, W. E. W. (2016). The Influence of Country-of-origin on Consumer Purchase Intention: The Mobile Phones Brand from China. Procedia Economics and Finance, 37(16), 343-349. https://doi.org/10.1016/s2212-5671(16)30135-6 